Kaija Kaitavuori

\title{
VÄLITTÄJÄT NYKYTAIDEMAAILMASSA
}

\section{tuotantoputkesta toimijaverkkoon}

\section{Intermediaries of the Artworld. From Pipeline to Actor-Network}

\begin{abstract}
Intermediaries of the Artworld. From Pipeline to Actor-Network looks at the different ways in which mediators or intermediaries in the cultural field have been conceptualised both in social theory (Becker, Danto, Dickie...) and by practitioners in the field of visual arts. The practical examples come mostly from discussions in Finland and from the visual arts.
\end{abstract}

The article claims that a linear view of art production as a producer-product-distribution-user chain is not sufficient to explain how art is created and enjoyed. Instead, we should look at the process and its divers actors as a network in which there are connections and movement in all directions, rather than just from artists via mediators to audience.

One case study, Santiago Sierra's project Man in a Ditch (2001), is analysed as an example of a coproduction between multiple actors. The role of the artist turns out to be that of 'cutting the network'.

Keywords: Intermediaries, mediating, curator, contemporary art, action-network-theory

Nathalie Heinichin mukaan nykytaidetta luonnehtii välittäjien korostunut rooli (Heinich 2014). Verrattuna klassisen tai modernin taiteen aikakauteen taiteen esillepääsy on riippuvaisempi kuin koskaan erilaisten valitsijoiden, managerien, tuottajien ja kuraattorien toimista. Nykytaiteen irtauduttua perinteisistä taiteeksi tunnistettavista muodoista vaaditaan myös yhä enemmän taiteen ympärille keskittyvää ja sitä legitimoivaa asiantuntijapuhetta ja -toimintaa (Heinich 2014, s. 89-113). Vera Zolberg puolestaan kuvaa 1970-luvun jälkeistä aikaa taidemuseomaailmassa "post-professionaaliseksi" vaiheeksi, jolloin erilaiset operationaaliset ja manageriaaliset toimijat ovat lisääntyneet niin, että niitä on jo enemmän kuin perinteisiä sisältöammattilaisia (Zolberg 2003). ${ }^{1}$ Taidekentän muutos merkitsee siis sekä välittäjäportaan paksuuntumista että rakenteellisia muutoksia siinä, miten taiteeseen erikoistuneet toimijat ovat järjestäytyneet.
Tämä kirjoitus tarkastelee käsityksiä ja teorioita siitä, mikä on näiden välittäjien rooli ja miten ne toimivat - toisin sanoen eri tapoja hahmottaa 'välittäjyys'. Tarkastelu suhteutuu kautta linjan Suomen taidekenttään ja etenkin kuvataiteen ja taidemuseoiden maailmaan sekä siellä käytäviin keskusteluihin välittäjien tehtävästä.

Taidekentän arkikäsitys välittäjyydestä perustuu pitkälti ymmärrykseen kentän rakenteesta lineaarisena tuotantoprosessina. Siinä taiteilija luo - suunnittelee ja valmistaa teoksen - yleensä yksin tai toisinaan ryhmässä. Seuraavassa vaiheessa teos tai projekti asetetaan esille. Tässä vaiheessa kuvaan tulevat välittäjät: kuraattorit, tuottajat ja museoihmiset, jotka valitsevat teoksia näyttelyyn, suunnittelevat esillepanoa, tuottavat tekstiä ja muuta aineistoa. Kolmantena paikalle saapuu yleisö, niin maallikot kuin ammattiyleisö. 
Ajatus siitä, että taiteilija ja taide on ensin ja vasta sitten kuvaan tulee välittäjä ja lopuksi myös yleisö, synnyttää usein toistetun väitteen, että välittäjiä ei olisi, jos ei olisi taidetta ja taiteilijoita, ja edelleen, että välittäjät elävät taiteilijoiden kustannuksella. Tätä ajatusta heijastavat esimerkiksi seuraavanlaiset kommentit: "Taideinstituutit, kuten museot, elävät taiteilijoiden ilmaistyöstä [...] Samalla näiden instituutioiden virkamiehet nauttivat itse kunnon palkkaa." (Karlsson-Sutisna \& Kuparinen 2012) ja "On väärin, että näyttelyä ripustavat ihmiset saavat liksaa, mutta minä [taiteilija] teen työni ilmaiseksi." (Heinänen 2009).

Tarkoitus ei ole tässä kyseenalaistaa taiteilijoiden toimeentulon niukkuutta, mihin yllä olevissa sitaateissa viitataan. On totta, että taiteen parissa tehdään paljon ilmaistyötä, mikä on ongelmallista. Sitä tekevät taiteilijoiden lisäksi myös ns. välittäjäportaan toimijat. Toimeentulon niukkuus synnyttää kilpailua, katkeruutta ja vastakkainasettelua, jota ruokitaan kuvaamalla, miten nämä muut "elävät taiteilijoiden kustannuksella", "repivät taiteilijan selkänahasta", ovat "loisia". Resurssien epätasaisen jakautumisen ja muuttuvien rahoitusrakenteiden ei kuitenkaan pidä antaa peittää monensuuntaisten riippuvuuksien verkostoa.

Välittäjien riippuvuus taiteen tekijöistä on tietenkin totta, mutta samalla ainoastaan osa totuudesta. Riippuvuus on molemminpuolista: myöskään taidetta ja taiteilijoita ei olisi ilman välittäjiä, ei ainakaan samassa muodossa. Yhtä hyvin kuin voidaan kyseenalaistaa taiteilijoiden riippumattomuus välittäjistä, voidaan lisäksi kysyä, olisiko taiteen välittäjiä tai taiteilijoitakaan olemassa ilman taiteen yleisöä. Taidepuhe kuitenkin suosii taiteilijan esittämistä konstruoimattomana, annettuna ja omaehtoisena.

Ajattelutapa, jossa toimijat asetetaan lähtökohtaisesti irralleen toisistaan tai jopa keskinäiseen ristiriitaan, on paitsi vallitseva arkikäsitys, common sense, myös akateemista tutkimusparadigmaa hallitseva näkökulma. Taiteentutkimus mieluiten rajaa taiteen irralleen muusta maailmasta ja (uusista virtauksista huolimatta) perinteisesti tutkii taideteoksia esineinä ja kuvina eikä prosesseina tai verkostoina. Myös so- siologinen taiteen tutkimus lähtee käsityksestä, jossa toiminnot nähdään erillisinä ja peräkkäisinä. Sosiologia ei myöskään halua sanoa mitään taiteesta 'taiteena' vaan käsittelee ainoastaan taiteen ehtoja tai kehyksiä siten, että kaikki 'muu', sosiaalinen, ymmärretään taustaksi, ei-taiteeksi (Heinich 2001, Karttunen 2015). Käsitys taiteesta ja taideteoksesta irrallisena itsenäisenä oliona ja taiteen tekemisen autonomiasta on aika lailla vankkumaton.

Yksiulotteinen ja yksisuuntainen tuottaja-teos-välittäjä-vastaanottaja-kaava antaa liian kapean kuvan todellisuudesta. Varsinkin nykytaide yhä enemmän rakentuu toisin: siinä virtausta on molempiin suuntiin ja erilaisten toimijoiden panokset risteytyvät aiempaa mutkikkaammalla tavalla. Muutos taiteessa edellyttää muutosta ajattelutavassa. Tämä artikkeli ehdottaa toisenlaista, verkostomuotoista jäsennystä.

\section{Kollektiivisen tuotannon malleja}

Taiteen tuotannon monitekijäisyyttä on toki pyritty kuvaamaan ennenkin etenkin erilaisten taidemaailma-käsitteiden valossa. $\mathrm{Ne}$ jäävät kuitenkin ainakin nykytilanteen suhteen puutteellisiksi. Seuraavassa kuvataan pääpiirteissään näitä teorioita ja pyritään sitten täydentämään kuvausta nykytilannetta vastaavaksi.

Howard Becker kuvasi klassikkoesseessään Art as Collective Action, mitä kaikkea tarvitaan, jotta sinfoniaorkesterin esitys olisi mahdollinen:

Jotta esimerkiksi sinfoniaorkesteri voisi esittää konsertin, on täytynyt kehittää, valmistaa ja huoltaa soittimet, keksiä nuottikirjoitus, säveltää musiikki käyttäen kyseistä nuottikirjoitusta, ihmisten on pitänyt opetella soittamaan soittimilla näitä nuotinnettuja säveliä, harjoituksia varten on täytynyt varata tilat ja ajat, konserttien mainokset on pitänyt levittää, tiedotus hoitaa ja liput myydä, ja paikalle on täytynyt saada kutsuttua yleisö, joka kykenee kuuntelemaan ja tavalla tai toisella ymmärtämään ja reagoimaan esitykseen. ${ }^{2}$ (Becker 1974, s. 767.) 
Kokonaisuudessa on mukana lukuisa joukko tekijöitä, jotka ovat toiminnassa jo ennen kuin sävellys syntyy ja sen esittäjät kokoontuvat soittamaan ja jotka tarvitaan, jotta tieto esityksestä saavuttaa kuulijat ja jotta esitykselle välttämätön yleisö olisi olemassa. Becker jakaa nämä toimijat ja niiden tekemiset taiteelliseen työhön ja tukitoimintoihin: ensin mainitut edellyttävät erityisiä lahjoja ja taitoja, jälkimmäiset ovat suorittavaa työtä ja bisnestä. Becker kuitenkin muistuttaa, että se mitkä toiminnot kuuluvat kumpaankin leiriin, perustuu sopimukseen ja on vaihdellut aikojen kuluessa.

Tämä 'taidemaailma' on edellytys taiteen olemassaololle. Beckeriä edeltävät, etenkin Arthur Danton ja George Dickien esteettis-filosofiset taidemaailma-teoretisoinnit pohtivat kysymystä siitä, miten teos tai esine tulee ymmärretyksi taiteena - miten taiteen ja ei-taiteen raja tulee määritellyksi. Danton vastaus on teoreettinen: taide edellyttää tulkintayhteisön - ammatillisen taidemaailman - jonka jakama taideteoria mahdollistaa esitetyn asian näkemisen taiteena, vaikka se ei visuaalisesti erottuisi muusta maailmasta (Danto 1964). ${ }^{3}$ Dickien selitys on institutionaalinen: taidetta ei voi määritellä minkään ontologian tai teorian pohjalta, vaan sen määrittyminen on jatkuva prosessi, johon osallistuu useita toimijoita (Dickie 1974). ${ }^{4}$

Taidemaailmalla on siis kaksi ulottuvuutta: Beckerin sosiologinen analyysi perkaa konkreettisesti taiteen tuotannon eri elementtejä ja kuvaa taiteen materiaalista ja sosiaalista tuottamista. Toisaalta dantolais-dickieläinen taidemaailma selittää, miten jokin tuotos saa taiteen aseman, siis kuvaa teoksen tuottamista taiteeksi. Sekään ei silti vielä kerro, miksi ja miten tällainen taidemaailma ylipäätään on mahdollinen ja miten se toimii, ts. miten tulkintayhteisö muodostuu ja miten määrittyvät asemat ja henkilöt, joilla on valtuudet osallistua taidemaailmaan ja siten taiteen määrittelyyn ja tuottamiseen. Siihen antaa paremmin vastauksia Pierre Bourdieun käsite 'taidekenttä' ja sillä vaikuttava kulttuurinen/symbolinen pääoma (Bourdieu 1993). Jos Becker listaa niitä konkreettisia edellytyksiä (niin materiaalisia kuin henkisiä), joita taiteen tuotannolle on, Bourdieun 'kenttä' analysoi sitä, miten taidemaailma on olemassa suhteellisen autonomisena alueena suhteessa muuhun yhteiskuntaan ja miten sen sisäinen dynamiikka toimii.

Beckerin esimerkkiä noudattavaa taiteensosiologista tutkimusta on myöhemmin alettu kutsua 'production of culture' tai 'social production of art' -traditioksi (Tanner 2010, esimerkkinä Wolff 1981). Nämä taiteen tuotantorakenteen kuvaukset näyttävät, että taideteos syntyy jo valmiiseen, sitä edeltävään toimintakenttään ja syntyy pitkälti sen kentän vaikutuksesta. Paljon tarvitaan jo ennen kuin taiteilija alkaa työnsä: taiteilijalle pitää olla ikään kuin 'tilaus' - maailma, johon taiteilijan tuotos tulee ja jossa se ymmärretään taiteeksi - sekä materiaalinen ja henkinen rakenne, joka kannattelee taiteilijan työtä. Tähän maailmaan kuuluvat koulutus, erikoistuneet mediat, kulttuuripoliittiset ohjelmat, välittäjäporras ja instituutiot sekä yleisö. Ne kaikki tuottavat taiteen, eivät vain esittele tai vastaanota jossain muualla valmiiksi tehtyä. Voidaan sanoa, että nykyisenlaista taidetta ei olisi, ellei tätä kaikkea "muuta" olisi. Esimerkki siitä, miten taiteen "ulkopuolisen" tekijän myös tiedostetaan vaikuttavan taiteen sisältöön, on verkossa kiertänyt leikillinen Taiteilijan vuosikello, joka näyttää miten rahoituskanavat ja niiden (oletettu) tahto vaikuttavat tuotettuun taiteeseen:

Helmikuu: SKR:n maakuntarahasto. Tee yhteisöprojekti Kalevalasta kotikaupunkiisi.

Maaliskuu: Taiken taiteilija-apurahat. Ole kansallisesti merkittävä kiltti ammattilainen.

Huhtikuu: Yhteishaku. Vaihda alaa.

Toukokuu: Wihurin rahasto. Sävellä geenitutkimuksesta nykyooppera jouhikolle.

Elokuu: Kordelin. Koosta isoisäsi sotavalokuvista installaatio.

Syyskuu: Koneen säätiö. Ole rohkea jotain jotain $3 \mathrm{D}$ ryijyn ontologia.

Lokakuu: SKR päärahasto. Pyydä kaikki kaverit mukaan monitaideprojektiin.

Marraskuu: Soittele pohjoismaiset kontaktit läpi ja lähetä ruotsinkielisille säätiöille joku "Re-imagining Nordicness" tms. näyttelyehdotus 
Joulukuu: Säätiöille palkattomaan työharjoitteluun.

'Production of culture' -mallit kuitenkin edelleen jäsentävät taiteen tuottamisen yksisuuntaisena prosessina tekijöiltä yleisölle eivätkä tarkastele käyttäjän aktiivista roolia prosessissa. Toiseksi ne käsittävät taiteen ja sosiaalisen toisistaan erillisiksi alueiksi: ${ }^{5}$ yhteiskunta on ikään kuin taiteen konteksti tai tausta ja sosiologia tutkii tätä 'taustaa' mutta ei sano mitään taiteen sisällöistä tai merkityksistä. ${ }^{6}$ Kolmanneksi ne tekevät selkeän eron taiteilijan työn ja muun välillä. Becker nimeää erottelun artistic / non-artistic työksi; Richard Caves puolestaan kutsuu eroa termeillä artistic / humdrum (Caves 2000). Jaottelu pitää yllä ajatusta siitä, että muu - rutiininomainen, arkipäiväinen - ei ole osa taidetta eikä tule osaksi taiteellista lopputulosta. Varsinkaan nykytaiteessa jaottelu ei toimi: ei ole mahdollista tietää, ainakaan etukäteen, mitkä toiminnot ovat taidetta tai tukirakennetta.

\section{Kentän prosessit}

Myös taidekentän toimijoita itseään on askarruttanut, miten kuvata sitä, mitä 'välissä tapahtuu ja millaisia rooleja siellä on. Valtion taidemuseossa laadittiin vuosina 2003-5 näyttelyn tekemisen prosessikuvaus. Sen tarkoitus oli kirjata ylös kohta kohdalta, mitä näyttelyn valmistelussa ja toteutuksessa eri vaiheissaan tapahtuu, ja tehdä näkyväksi eri toimintayksiköiden ja ammattiryhmien työ. Käytännöllisenä tavoitteena oli luoda työkalu prosessien parempaan hallintaan ja ammattiryhmien väliseen yhteistyöhön, mutta yleisellä tasolla kiinnostavaa oli jo sinänsä asiantuntijuuksien tekeminen näkyväksi.

Prosessikuvaus rakentui horisontaalisessa suunnassa aikajanalle suunnittelu-, tutkimus- ja valmisteluvaiheeseen ennen avajaisia, näyttelyn varsinaiseen aukioloon sekä näyttelyn sulkeutumisen jälkeiseen aikaan. Vertikaalisesti kuvauksessa esitettiin ikään kuin kerroksina eri tavalla taiteen tuotantoon ja esillepanoon osallistuvat ammattiryhmät tai toiminnot, jotka kukin toteuttavat yhtä siivua laajassa ja moniulotteises- sa kokonaisuudessa. Näitä tunnistettiin pitkälti toista kymmentä: (prosessikuvausta hieman soveltaen) kuratointi, pedagogia, tapahtumat, yleisöpalvelu, viestintä, markkinointi, sponsorointi, hallinto ja talous, lakiasiat, konservointi, tekniikka ja logistiikka (ml. kiinteistö, IT), turvallisuus, kuvaus ja dokumentointi, arkistot (Kaitavuori \& Roine 2006, Kaitavuori 2007). Nämä ovat kaikki välittäjäportaan toimintoja, joiden yhteistyön tuloksena syntyy taidenäyttely. Suuressa instituutiossa yhteen näyttelyyn osallistuu melkoinen joukko eri alojen ammattilaisia, jotka kaikki hoitavat oman osuutensa. Pienissä tuotannoissa yksi ihminen hoitaa useampia tehtäviä ja yksittäinen galleristi voi kattaa jossain muodossa suurimman osan yksin. Humdrum/ artistic-jaon sijaan prosessikuvaus puhuu ydintoiminnoista ja tukitoiminnoista.

Uusien ammattialueiden (viestintä, markkinointi jne.) lisäksi Zolbergin kuvaamalla post-professionaalisella ajalla perinteisen museotyön ja näyttelyn tekemisen toiminnot ovat erikoistuneet ja eriytyneet yhä pidemmälle. Museoiden alkuaikoina kuraattorit (tai intendentit) olivat tekemisissä sekä esineiden että ihmisten kanssa: he valitsivat ja asettivat teokset esille ja myös esittelivät niitä yleisölle (Woollard 2006). ${ }^{7}$ Nykyään yleisö ei juuri tapaa kuraattoreita, paitsi poikkeuksellisesti ohjelmapaikoilla kuten "kuraattorikierroksilla". Yleisökontaktit ovat paljolti erikoistuneen ammattiryhmän käsissä: museolehtorit, oppaat ja taidekasvattajat vastaanottavat tiedonjanoiset näyttelykävijät. Kärjistetysti sanoen taidemuseossa kuraattorin prioriteetti on taiteilija ja taide, pedagogin (tai yleisötyöntekijän) prioriteetti on katsoja, yleisö. ${ }^{8}$ Toiset valitsevat ja asettavat taidetta esille, toiset huolehtivat niistä, jotka tulevat sitä katsomaan. Tämä ei tarkoita, etteikö kuraattori olisi kiinnostunut yleisöistä ja vielä vähemmän sitä, ettei pedagogi olisi kiinnostunut taiteesta - ero viittaa työnjakoon ja ammatilliseen eriytymiseen. Kun kuraattori huolehtii siitä, että taiteilijan näkemys saa parhaan mahdollisen toteutuksen, pedagogi katsoo näyttelyä ja koko instituutiota kävijän ja katsojan näkökulmasta ja pyrkii edesauttamaan kohtaamista taiteen kanssa.

Niin kuraattorin kuin museolehtorin tehtävät ovat kehittyneet omiksi ammateikseen - 
kummallakin on omat konferenssit, julkaisut, yhteisöt ja yhdistykset. Niihin on kehittynyt omat rutiinit, konventiot, käsitteet ja puhetavat - sanalla sanoen oma ammatti-identiteetti. Molemmat professiot ovat varsin nuoria ja koulutus uutta; etenkin Suomessa eriytyminen on tapahtunut vain vähän aikaa sitten tai vasta tapahtumassa. $^{9}$

Näiden ns. välittäjäammattien tutkimus keskittyy usein taloudellisten kysymysten ympärille. Välittäjät nähdään joko portinvartijoina, jotka säätelevät pääsyä taiteen markkinoille, tai kuluttajiin suuntautuvina maun ja halujen muokkaajina. Välittäjien tehtävä nähdään ennen kaikkea kulttuurin ja talouden leikkauspisteessä taloudellisen arvon luojana ja taidetuotteiden markkinoijana (Smith Maguire \& Matthews 2014, s. 1-10, 100-112). Myös juridisen näkökulman tutkimuksessa painopisteenä on pääasiassa taiteen myyminen ja ostaminen (Caves 2000). Suomessa välittäjäportaan ammatillisen erikoistumisen systemaattinen tutkimus on vähäistä ellei olematonta. ${ }^{10}$

Valtion taidemuseon prosessikuvaus oli yritys kuvata välittäjäkerroksen moninaisuutta käytännön näkökulmasta. Kuvaukseen kirjattiin kosketuspisteitä eri toimijoiden välille ja etenkin solmukohtia, joissa eri ammattialueiden yhteispeli on ratkaisevaa. Näihin kohtiin kirjattiin lisäksi eräänlaisia muistilistoja eri toimista, jotka kuhunkin ajankohtaan mennessä oli saatettava valmiiksi. Kuvauksiin tallentuu paljon eri ammattialueiden piilevää tietoa näyttelyprosessista. Prosessikuvaus tarkastelee taidetta, niin kuin oli tarkoituskin, välittäjäportaan näkökulmasta. Taiteilija ja yleisö putoavat ikään kuin kuvauksen ulkopuolelle ja esiintyvät ainoastaan siinä roolissa, jossa ne näyttäytyvät museoammattilaisten työssä.

\section{Putkimallista verkostoon}

Yllä olevassa taiteen tuotannon kollektiivisuus ja laajemmin välittäjyys on ymmärretty ammattitehtäviin liittyvänä asiana. Taiteen 'välittyneisyyttä, asioiden liittymistä ja toimijoiden vaikutusta toisiinsa voi kuitenkin tarkastella laajemmin ja etenkin nykytaiteen kannalta tar- koituksenmukaisemmin. Seuraavassa tarkastellaan tapausesimerkin valossa, miten perinteinen yksisuuntainen ja toimijoita kategorisoiva kuvaus täydentyy moniulotteiseksi ja 'litteäksi' verkostoksi. Santiago Sierran projekti Mies kuopassa, Person in the Ditch (2001), toteutettiin ARS01-näyttelyn yhteydessä Kiasman takapihalle. Lyhykäisyydessään kyseessä oli maahan kaivettu kuoppa, jossa istui asunnoton ihminen kahdeksan tuntia päivässä. ${ }^{11}$ Tarkastelun avuksi otetaan työkaluja toimijaverkkoteoriasta (action-network-theory ANT) sekä produser-käsite.

Bruno Latour ja ANT (Latour 2007) käyttää intermediary-termiä eri merkityksessä kuin yllä kuvattu välittäjäportaan tutkimus (Heinich, Smith Maguire \& Matthews, Caves). ${ }^{12}$ ANT-merkityksessä intermediary on välittäjä, joka ei muuta prosessiin osallistuvien tekijöiden luonnetta, kuten postinkantaja ei vaikuta toimittamansa kirjeen sisältöön tai muotoon mitenkään - ainakaan niin ei ole tarkoitus. Sen sijaan mediator yhdistää elementtejä siten, että ne muuttuvat prosessissa ja syntyy jotain uutta: hybridi tai kvasiobjekti. Latourin malliesimerkki on ihmisen ja aseen yhdistelmä, joka on enemmän kuin kumpikaan osa itsenäisenä (Latour 1999, s. 179). Aseihminen tai ihmisase (citizen-gun) on toimija, aktantti, joka käyttäytyy eri tavalla kuin kumpikaan osansa ilman toista. Latour ei ole kiinnostunut intermediary-tyyppisistä välittäjistä; sen sijaan kiinnostuksen kohteena ovat mediator-välittäjät ja välitykset, joissa toisensa kohtaavat asiat muuttuvat ja syntyy jotain uutta. Jos posteljooni piirtelisi viestejä kirjekuoreen tai anastaisi sisällön, hän astuisi mediaattoriksi.

Toisin sanoen välittäjäportaan toimijat, joita yllä kutsutaan termillä intermediaries, ovat latourilaisessa katsannossa mediaattoreita, sillä he nimenomaan osallistuvat taideteoksin syntyprosessiin. Museon kuraattorit valitsivat Sierran osaksi näyttelyä ja vastasivat teoksen tekstuaalisesta kehystämisestä ARS01-näyttelyn teemoihin, jotka käsittelivät mm. globalisaatiota. Teoksen aiheeksi valikoitui asunnottomuus, kun taiteilija oli tutustumassa Suomeen museon kutsusta ja luki museon toimittamaa aineistoa suomalaisesta yhteiskunnasta. Kuraattorit hoi- 
tivat myös käytännön toteutuksen eli ottivat yhteyttä Vailla vakinaista asuntoa ry:hyn, joka "toimitti" asunnottoman ihmisen kuoppaan. Museo huolehti myös teoksen fyysisestä toteutuksesta. Maahan kaivetun 3 × 5 × 3 metrin kuopan toteutti museon tekninen tiimi, joka tilasi kaivausoperaation Helsingin kaupungilta, joka puolestaan osti palvelun yksityiseltä firmalta. Tekniikka hankki kuoppaan tuolin ja katoksen sateen ja auringon suojaksi.

Taiteilija ei osallistunut teoksen varsinaiseen toteutukseen mitenkään; hän ei edes nähnyt sitä valmiina, vaan oli jo poistunut maasta, kun ensimmäinen asunnoton laskeutui kuoppaan. Hän toimi mediaattorina toisella tavalla: hän keksi yhdistää toisiinsa ihmisen ja kuopan, ja loi odottamattoman hybridin "mies kuopassa”. Siitä tuli 'aktantti', joka puolestaan vaikutti muihin toimijoihin: se muutti paikalle saapuvat ihmiset yleisöksi ja vaikutti heidän toimiinsa ja käyttäytymiseensä. Kuoppa toimi eräänlaisena käänteisenä jalustana istujalle erottaen tämän katsojista. Teos imaisi heidät hierarkkisen, eriarvoistavan rakenteen osaksi töllistelemään kuoppaan ajettua miestä. Teoksesta tuli sosiaalinen tilanne.

Katsojat ovat siten tärkeä osa teosta - muuten taiteilijan rakentama tilanne ei toimisi. Mies-kuoppa-yhdistelmä ei olisi ollut mahdollinen myöskään ilman taidenäyttelykontekstia - joka oikeastaan ei ole vain konteksti vaan osa teosta. ${ }^{13}$ Hybridi pysyi kasassa vain näyttelyn ajan. Näyttely ja sen tuottanut museo ovat osa mutkikasta ihmisten, toimien ja käytäntöjen verkostoa. Taiteilija osana tätä nykytaiteen verkostoa on eräänlainen brändi, "Santiago Sierra", jolta taidetta tunteva yleisö on tottunut odottamaan tietyn tyyppisiä teoksia. Sierra on jäävuoren huippu, joka pistää esiin massasta mutta jonka alle peittyy valtavasti taideopiskelijoita ja vähemmän kuuluisia taiteilijoita. Gregory Sholetten mukaan he ovat 'dark matter', pimeää ainetta, jonka ansiosta muutamat nimet voivat nousta mutta joka itse ei pääse hyötymään menestyksestä (Sholette 2011).

Kuopassa istuva ihminen oli oleellinen osa teosta ja sen konkreettinen materiaali. Ainoa asia mitä hänestä kerrottiin oli, että hän on asunnoton. Ilmeistä oli myös, että hän on mies. Todellisuudessa miehiä oli muutama, jotka hoitivat istumisen vuoroissa. Vailla vakinaista asuntoa ry järjesti miesten rekrytoinnin ja yhteydenpidon. Yhdistyksen nimi samoin kuin sen kokoamien ihmisten asema perustuu kotikuntalain määritelmään asunnottomuudesta. Miehet ovat siis juridisen, hallinnollisen ja sosiaalisen verkoston osia. Yksi heistä oli Reijo, joka tuolloin oli joutunut asunnottomaksi monen tapahtuman (ero, perheen hajoaminen, työpaikan menetys, alkoholi, asunnon menetys) summana. Mahdollisuus ansaita vähän ylimääräistä oli tervetullut tilaisuus. Kaikilla yksityiskohdilla oli merkitystä hänen osumiseensa teoksen osaksi, mutta mikään niistä tai hänen nimensä ei tullut mukaan teokseen. Sen sijaan taiteilija oli asettanut esille tilastotietoa Suomen asunnottomien määrästä sekä korvaussumman, jonka istujat saivat. Sierra pitää myös oman yksityisen persoonansa visusti poissa teoksesta (toisin kuin vaikkapa Jeff Koons) eikä juuri esiinny julkisuudessa muutenkaan.

Taiteilija oli siis määritellyt, mitkä asiat kuuluivat teokseen ja mitkä jäivät sen ulkopuolelle (vaikka olivat vaikuttavia itse teoksen toteutumisessa). Teoksen tuotantoon osallistui myös joukko ennalta arvaamattomia tekijöitä. Turvallisuusmääräysten mukaisesti kuoppa piti tukea teräspalkeilla - ne eivät siis olleet taiteellinen ratkaisu. Kuopan paikkakin oli kompromissi, sillä sen piti pysyä museon tontilla, vaikka taiteilija olisi halunnut sen lähemmäs eduskuntataloa. Kuopan sijoitukseen vaikutti myös peruskallio, joka joissain paikoin rajoitti kaivamista. Lisäksi kuoppa oli mahdollista nähdä Kiasman sisältä, josta pystyi tarkkailemaan koko tilannetta kuopan reunan katsojineen ikään kuin ulkopuolelta. Toisinaan Reijo huvitti itseään vilkuttamalla kuopasta ikkunasta katsoville ihmisille. Tämä ei tietenkään ollut taiteilijan suunnittelema osa teosta.

Sattumalla tai väärinkäsityksellä oli niin ikään osuutensa teoksen toteutuksessa. Taiteilija ilmeisesti tulkitsi väärin asunnottomuudesta kertovia aineistoja, sillä teosteksti väittää, että (vuonna 2001) Helsingissä olisi 10000 asunnotonta. Sierra lienee sotkenut luvun koko maan asunnottomiin (9960 ihmistä), Helsingissä heitä oli 4700 (ympäristöministeriön tiedote). Voi 
jopa kysyä, olisiko asunnottomuus valikoitunut teoksen aiheeksi, ellei taiteilija olisi erehdyksessä liioitellut ongelman vakavuutta ja asunnottomien määrää yli kaksinkertaiseksi.

Tapahtumasta jäljelle jäänyt valokuvateos on sekin monen tekijän yhteistuotos. Museon valokuvaaja video- ja stillkuvasi teosta sen esilläoloajan. Kun kuoppa määräajan päätyttyä luotiin umpeen, video oli esillä näyttelyn loppuun asti. Se lähetettiin myös taiteilijalle, joka valitsi siitä kaksi pysäytyskuvaa. Nämä kuvat vedostettiin mustavalkoisiksi kuviksi, jotka taiteilija signeerasi taideteoksinaan. Sierra ei siis tässäkään vaiheessa osallistunut teoksen konkreettiseen toteuttamiseen. Taiteilijan gallerian kautta teos kytkeytyy taidekauppaan: galleria myi vedokset, yhden myös projektin tuottaneelle Kiasmalle, jonka kokoelmiin teos päätyi. Aikaan sidotulla projektilla on näin eräänlainen toinen elämä. Numeerinen virhe Helsingin asunnottomista kiertää kuvan mukana.

Teos Mies kuopassa rakentui monen toimijan yhteistyössä ja se koostui useasta elementistä, jotka jokainen itsessään olivat lukuisien verkostojen osia. Kuvauksesta puuttuu monta elementtiä, esimerkiksi lakiasioiden ja sopimusten osuus tai museon pedagogiset palvelut. Lisäksi jokaisesta teoksen linkistä avautuu periaatteessa rajoittamaton verkosto moneen suuntaan - tarkastelua voisi jatkaa Reijon ex-vaimoon, kuopan kaivaneeseen työmieheen tai valokuvan vedostajaan. Haasteeksi muodostuukin, miten taideteoksen tarkastelussa toimijaverkosto ja sen kytkennät rajataan. Tähän palataan artikkelin lopussa.

\section{Yleisö, osallistuja vai tuottaja-käyttäjä}

Nykytaiteen erityispiirre on yleisön aktiivinen rooli. Tai oikeammin: yleisö voi katsojaposition lisäksi toimia osallistujana. Osallistumisen tapoja on useita. Mies kuopassa -teoksessa asunnoton ihminen osallistui teokseen sen osana; muut ihmiset osallistuivat teoksen katsojina, mutta siinäkin roolissa teoksen täydentäjinä. Sekä taiteilijat että taiteen teoreetikot jättävät kuitenkin usein maallikkoyleisön mainitsematta kiistellessään taidemaailman hierarkioista ja taiteen olemassaolon edellytyksistä. Tai kun yleisö mainitaan, se voidaan asettaa taiteilijaa hyväksikäyttävän ravintoketjun päätepisteeksi: "Haluan vain muistuttaa taiteenharrastajille, mitä he tekevät ravitessaan itseään taiteella. (...) Syövät ihmistä." (Nylén 2015). Samoin Danton ja Dickien taidemaailmat koostuvat vain ammattilaisista. Taidemaailmateoreetikoista ainoastaan Becker antaa myös ei-ammattimaiselle yleisölle painoarvoa. Aktiivisen yleisön malleja löytyykin paremmin muualta kuten tavara-, palvelu- ja tiedontuotannon mallinnuksista.

Taiteilija-teos-esillepano-yleisö-jatkumo muistuttaa teollista tavaratuotannon alkutuotanto-jalostus-jakelu-kulutus-mallia. Yhtä vähän kuin taiteen putkimalli kuvaa taiteen tuotantoa, teollinen tuotantomallikaan ei enää kuvaa hyödyketuotannon rakennetta. Postfordistisessa maailmassa kuluttajat osallistuvat yhä enemmän tuotteiden ja palveluiden kehittämiseen, ja valmistajien, jakelun ja kuluttajien välillä on luuppeja ja takaisinsyöttöä siinä määrin, ettei ole mahdollista erottaa eri vaiheita toisistaan kronologisesti eikä rakenteellisesti. Tätä asiaintilaa on pyritty kuvaamaan $\mathrm{mm}$. prosumer- tai produser-käsitteiden avulla. Termeillä on lievästi eri merkitys. Prosumer-käsitteen loi Alvin Toffler jo 1970-luvun alussa kuvaamaan asiantuntevaa ja vaativaa asiakasta, joka haluaa osallistua tuotteiden kehittämiseen ja kustomointiin, siis eräänlaista aktiivista kuluttajaa (Toffler 1970). Vastaavia termejä ovat pro-am (Leadbeater \& Miller 2004) tai citizen-consumer (Hartley 2008), jotka niin ikään kuvaavat osallistuvaa asiantuntijakuluttajaa. Lisäksi ajatukset erilaisista commons-based peer production (Yochai Benkler 2006) tai crowdsourcing-menetelmistä (Howe 2006) antavat palveluiden ja tuotteiden käyttäjille valtaa ja vastuuta vertaistuotannon tai joukkoistamisen muodossa. Tällaisia tuotantotapoja on monella alueella, usein mainittuja ovat erilaiset tekniset tutkimus- ja kehitysprojektit, online-pelit sekä TV- tai nettijournalismi; tiedonvälityksessä muutos kuvaa siirtymistä broadcast-moodista broadband-verkostotuotantoon. Mielestäni toimivin on kuitenkin uudiskäsite produser, joka yhdistää tuottajan (producer) ja käyttäjän (user): prod-user.

Produser, Axel Brunsin kehittämä termi, 
on enemmän kuin käsiteamalgaami - se kuvaa kokonaista toimintafilosofian muutosta (Bruns 2006 \& 2008). Tässäkään käyttäjä ei ole tuotantoketjun viimeisenä lenkkinä vaan käyttäminen on samalla tuottamista. Lisäksi Bruns analysoi tarkemmin, mistä produsage-tuottamisessa on kyse. Sitä luonnehtii tuotantoprosessin avaaminen suljetun erikoisasiantuntijapiirin ulkopuolelle sekä tästä seuraava periaate joustavista ja vaihtelevista toimijapositioista. Osallistujan tehtävä saattaa siis vaihdella projektien välillä tai saman projektin sisällä kykyjen ja kiinnostuksen mukaan. Tämä ei tarkoita täydellistä tasa-arvoa (tai kaaosta kuten usein näkee väitettävän): projekteilla voi olla selkeä aloittaja ja johtaja, mutta hänen roolinsa on jatkuvasti avoimen neuvottelun kohteena. Projektit toimivat heterarkian, eivät hierarkian pohjalta. Tuotosta taas määrittelee se, että sen levitys on samanaikaista tuotannon kanssa; ei siis ole ensin valmista tuotetta, joka välitetään käyttäjille vaan prosessit tapahtuvat samaan aikaan. Produsage-prosessissa ei myöskään ole etukäteiskontrollia, sillä tarkoitus on juuri saada mukaan monen yksittäisen toimijan luovuus. Tuote ei joka tapauksessa ole lopullinen vaan prosessi, jossa uudet versiot korvaavat vanhat. Prosessi kyllä tuottaa myös artefakteja, mutta niistä kehitellään jatkuvasti uusia malleja uusiin tarkoituksiin. Malliesimerkkinä yleensä mainitaan tietysti Wikipedia, mutta produser kuvaa mainiosti myös mm. osallistavan tai yhteisöllisen nykytaiteen tuottamista, jossa monen alan ihmiset osallistuvat teosten tekemiseen ja käyttämiseen. Tämän artikkelin teeman yhteydessä malli on relevantti yleisemmin taiteen tuotantokentän tarkasteluun. Taidekaan ei synny yksisuuntaisessa tekijä-tuotos-välittäjä-vastaanottaja-putkessa, vaan virtausta on molempiin suuntiin ja eri toimijoiden välillä. Kyseessä ei ole yhden toiminnon riippuvuus edellisestä vaan monisyinen riippuvuuksien verkosto, jossa toimijaroolit ja asiantuntijuudet vaihtelevat.

Ainoa piirre, joka Brunsin mallissa ei sovi taiteen kenttään, on avoimia tuotantoprosesseja leimaava omistajuuden jakaminen: taidemaailma instituutiona lepää yksilötuottajan varassa ja taidemarkkinoilla aina tarvitaan omistaja. Produsage-tuotannoissa puolestaan yksi teki- jä ei voi omia joukon tuotetta vain omiin nimiinsä ja asia hoidetaan yleensä open source tai commons-ratkaisuilla. Taidekenttä kuitenkin rakentuu vahvasti yksilöllisen tekijyyden varaan ja taiteilijan institutionaalinen rooli on, edelleen, olla poikkeusyksilö, joka yksin vastaa taiteen tuottamisesta ja jolla on kyseenalaistamaton omistajuus tuotettuun taiteeseen: vaikka taloudellinen omistajuus vaihtuisi, tekijänoikeus säilyy taiteilijalla. Tätä kyseenalaistavia tendenssejä ja projekteja kyllä on, mutta ne aiheuttavat aina jännitteitä kentän toimintaan ja tuntuvat rikkovan sen logiikkaa. Taidekenttä on jonkinlainen sekoitus uutta ja vanhaa, lateraalia verkostoa ja vertikaalia hierarkiaa.

Kun taidetuotannon putkimalliin liittyvä ajallinen, ketjumainen ajatus vaihdetaan produser-mallin kenttämäiseksi rakenteeksi, tulee mahdolliseksi ajatella eri toimijoiden panosta taideprosessissa monipuolisemmin ja tarkastella roolien välisiä suhteita vaihtuvina positioina, joiden välinen riippuvuus ei ole sidottu kronologiaan. Topografisessa mallissa kaikki voivat toimia omalla tavallaan prosessissa impulssien lähettäjinä ja vastaanottajina. ANT-ajattelu laajentaa toimijoiden piiriä myös ei-elollisiin aktantteihin. Kun 'välittäjyys' ymmärretään ajallisesti, välittäjäammattien toimijat nähdään diilereinä, jotka toimittavat valmiita taideteoksia tekijöiltä yleisöille: tuotanto tapahtuu ensin ja välitys ja vastaanotto seuraavat sitä ajallisesti erillisinä vaiheina. Tietyntyyppisen taiteen osalta tämä toimiikin, mutta yhä useammin kuitenkin, kuten todettu, valmistus-, välitysja vastaanottoprosessit kietoutuvat toisiinsa monin ristiinkytkennöin. Heinich kuvaa eroa näiden prosessien välillä nimeämällä ne taiteen teostaloudeksi ja projektitaloudeksi (économie d'oeuvres, économie de projets): teoslogiikka, so. perinteinen välitystalous on edelleen pitkälti toiminnassa galleria- ja messutaiteen kentällä; taideinstituutiot (museot, taidehallit yms.) sen sijaan operoivat projektilogiikan ehdoilla (Heinich 2014, s. 217-220). Toimintamallit ovat toisistaan melko erillään ja täydentävät toisistaan, mutta samaan aikaan ovat osin kilpailuasemassa. Kentillä vallitsee eri säännöt ja onnistumista arvioidaan eri kriteerein: toista määrittää myynti ja taloudellinen tulos; toinen on subventoitua, 
toiminta perustuu kutsuihin ja tilaustuotantoihin ja arvostus perustuu näkyvyyteen ja maineeseen.

Suuntautuminen joko yleisöön tai taiteilijaan määrittää pitkälti ammatillisen välittäjäportaan rooleja, etenkin kuraattorien ja pedagogien työnjakoa. Jakautuneisuus tulee esiin muun muassa siinä, että kuraattoreja käsittelevissä tai kuraattorien omissa tekstissä ei usein edes mainita yleisöä (Björk 2015). Myös taiteilijoiden kuulee sanovan, etteivät he tarvitse ketään katsojaa luodessaan taidetta, vaan tekevät sitä itselleen ja vertaispiirilleen. ${ }^{14}$ Yleisö- ja taiteilijasuuntautuneisuuteen liittyy paitsi erilaisia työtehtäviä myös erilainen arvostus, sillä yleisöä, kuten todettu, ei pidetä osana taidemaailmaa. Ammattiroolin kannalta yleisötyötä vaivaa näkymättömyys: se ei useinkaan näy tavalliselle kävijälle eikä muille ammattilaisille kuin pieninä vilauksina eikä se nouse otsikoihin paitsi silloin, kun sen koetaan epäonnistuvan. Voisi pikemmin sanoa, että toiminnan koetaan onnistuvan silloin, kun se on huomaamatonta. Silloin kun yleisötyöstä kirjoitetaan mediassa, kyseessä on usein hyökkäys sitä vastaan. ${ }^{15}$ Arkipäivän vihamielisyys, yleisön halveksunta ja arvostuksen puute on taidemaailman sisällä paikoin aika rankkaakin. ${ }^{16}$ Neutraali pedagogisen toiminnan uutisointi tai analysointi on mediassa harvinaista.

Myös kuratointi tapahtuu suurelta osin ns. kulissien takana, mutta kuraattori on kuitenkin eri tavalla näkyvä hahmo. Vaikka vain murto-osa on ns. tähtikuraattoreita, liittyy kuraattorin imagoon erityistä prestiisiä. Kuraattori seisoo taiteilijan rinnalla ja saa osansa tämän 'säteilystä' - toisinaan loistaa jopa kirkkaampana kuin taiteilija. Pedagogi taas asettuu yleisön rinnalle. Ei-ammattimaiseen maallikkoyleisöön suuntautuva toiminta ei nauti kentän erityisyyttä vaalivassa taidemaailmassa samaa arvostusta kuin taiteen erikoisalaa vahvistava kuraattorin työ. Arvoasemaan ei voi olla liittymättä myös yleisötyön alan lähes sataprosenttinen naisvaltaisuus.

Statuseroa on selitetty mm. sillä, että taidemaailmassa taiteilijat ja kuraattorit toimivat reputation economy-logiikan mukaisesti, kun taas pedagoginen toiminta kuuluu service economy -alueelle (Mick Wilson, siteerattu: Kaitavuori 2013). Ensin mainittu on autonomista toimintaa, joka on itse vastuussa omista arvoistaan ja perustuu yksilöiden luomalle maineelle; jälkimmäinen taas on alisteista muiden toimintalogiikalle ja palvelee näitä. Sisäistettyä erottelua kuvaa myös se, että kuraattoreiden on mahdollista nähdä tehtävänsä taiteena, pedagogeille tämä ei juurikaan tule mieleen. ${ }^{17}$ Palvelueetokseen perustuva selitys sysää yleisöön suuntautuvan toiminnan (bourdieulaisen suhteellisen autonomisen) taidekentän laitamille tai oikeastaan sen ulkopuolelle. Kuraattorin sallitaan kiilata taiteilijan rinnalle osaksi mainetaloutta ja taidetta; yleisöön suuntautuvan toiminnan sen sijaan ajatellaan tapahtuvan tämän luomisvaiheen jälkeen ja eräänlaisena lisätoimintona. Asetelmassa voi aistia taistelua kentän asemista sen suhteen, mikä on artistic ja mikä support tai humdrum-toimintaa - toisin sanoen millainen toiminta kasvattaa kulttuurista pääomaa.

\section{Lopuksi}

Perinteinen lineaarinen malli ei ehkä koskaan ole kuvannut taiteen tuottamista todenmukaisesti, mutta varsinkin nykytaide tuo prosessiin uusia aspekteja. Vanha malli ei ota huomioon taidetta, joka on prosessi tai joka on vasta alusta tapahtumiselle tai sitä että erilaisten osallistavien teosten valmistamiseen osallistuu myös maallikkoja. Se ei myöskään huomioi sitä, että kuratointi aktiivisesti tuottaa taideteoksia tai että projekti ehkä materialisoituu vasta dokumentaationa tai ylipäätään että käytännössä suurten taideprojektien toteutus on suuren joukon yhteistyötä. Yleisöä ei myöskään nähdä osana taidetta vaan totaalisesti ulkopuolisena. Verkostokuvaus tuo nämä elementit osaksi taideprojektia ja lisäksi laajentaa prosessia ei-elollisten toimijoiden piiriin. ${ }^{18}$

Tapauskuvaus näyttää, että ei ole mitään sääntöä, joka rajaisi jotkin toiminnot, tekijät tai elementit automaattisesti taiteen sisä- tai ulkopuolelle. Sierran teoksessa terästukia ja peruskalliota ei ollut tarkoitettu osaksi teosta, toisin sanoen niihin ei ollut tarkoitus kiinnittää erityistä huomiota, vaikka ne olivat välttämätön 
osa teoksen rakennetta. Ai Weiwein teoksissa Straight ja Forge (2008-2012) oli toisin. Teokset rakentuivat vuonna 2008 Setsuanin maanjäristyksessä tuhoutuneen koulun elementeistä, jonka alle kuoli yli viisituhatta lasta. Järkkynyt peruskallio ja huonosti rakennetut terästuet nimenomaan olivat teoksen ydintä. Sierra ei myöskään ollut kiinnostunut osallistujan henkilöön liittyvistä piirteistä tai katsojan aatoksista teoksen äärellä. Yhteisötaide puolestaan yleensä pitää osallistujien henkilökohtaisia tarinoita tärkeinä ja monesti myös katsojalta kysytään reaktioita teokseen, esimerkiksi Ai Weiwei oli rakentanut osaksi teostaan Sunflower Seeds Tate Modernissa katsojakommenttien alustan. Kaiken lisäksi taiteilijat sekoittavat perinteisiä tuotantoputken rooliasetelmia tekemällä taidetta välittäjäportaasta. Erwin Wurmin Be nice to your curator (2006) koostuu performanssista ja kuvista, joissa hän kantaa kuraattoria sylissään tai syöttää tätä. Andrea Fraser puolestaan on viettänyt intiimin hotelliyön taiteen keräilijän kanssa ja tallentanut sen videolle (Untitled 2003), jonka keräilijä osti kokoelmaansa. Näissä kuraattori onkin teoksen materiaalia eikä sen näkymätön tuottaja.

Mikään 'taidemaailma' ei siis voi kertoa, mikä kuuluu tai ei kuulu teokseen. Nykytaiteen osalta mikään ei ylipäätään ennalta säätele, mitkä maailman osaset - aineelliset tai aineettomat - voivat toimia taiteen materiaalina. ${ }^{19} \mathrm{Ei}$ ole myöskään mielekästä tehdä ennalta erottelua taiteellisen ja 'muun' välillä tai mieltää yhteiskunta taiteesta erillään olevaksi taustaksi tai kontekstiksi; yhteiskunta on osa taidetta pikemmin kuin toisin päin.

Viime kädessä taiteilijan tehtävä on toimia verkoston rajaajana tai leikkaajana, päättää missä ovat teoksen rajat. Kuten Sierran esimerkki kertoo, käytännön toteutuksessa taiteilijalla voi olla minimaalinen osuus. Hänen roolinsa on saattaa yhteen elementtejä (asunnoton, kuoppa) uusiksi kvasiobjekteiksi ja toisaalta rajata pois toisia elementtejä. Päätös siitä, mitkä elementit ovat merkitseviä ja mitkä eivät, on sattumanvarainen siinä mielessä, että mikään esivalinta ei rajaa sitä. Siksi taideteoksen osia koskevat päätökset ovat merkityksellisiä, poliittisia: ne voisivat olla toisinkin.
Katkaisemalla verkoston ja sulkemalla osia teoksen ulkopuolelle taiteilija ohjaa merkityksenmuodostusta. Kun kuopassa istuvan henkilön persoona on rajattu pois, hänestä tulee osa statistiikkaa, osanen joka on korvattavissa toisella: kuka tahansa koditon. Samaan tapaan kuopan reunalla tirkistelevät katsojat ovat teoksen rakenteellisia elementtejä eikä heidän yksilöllisyytensä mitenkään korostu. Huomio kohdentuu yhteiskunnan rakenteeseen liittyviin suhteisiin eikä henkilösuhteisiin. Taiteilijan tarkoitus ja verkoston rajojen hallinta ei kuitenkaan aina onnistu täydellisesti vaan maailma valuu teokseen sisään: kuopasta vilkutteleva Reijo, tilaston virheellinen tulkinta tai oikukas peruskallio vaativat huomiota omalle toimijuudelleen, ryhtyvät aktanteiksi taiteilijalta lupaa kysymättä.

Mitä siis tutkijan pitäisi tutkia? Latourin ohje "Follow the actors!" (Latour 2007) johtaa loputtomaan yhteyksien suohon. Toisaalta huomion kiinnittäminen vain taiteilijan taiteeksi määräämiin elementteihin jättää varjoon suuren ellei peräti suurimman osan vaikuttavista tekijöistä. Kiinnostavia alueita ovatkin ehkä juuri katkaisun paikat ja ne tilanteet, joissa odottamattomat toimijat aktivoituvat ja oletetut toimijaroolit vaihtavat paikkaa. Niissä taiteen verkostoluonne tulee selvimmin näkyviin. 
Alexander, V. (2003). Sociology of the Arts. Oxford: Blackwell.

Becker, H. (1974). Art as Collective Action, American Sociological Review, 39(6), 767-776. Myöh. pohjana ensimmäiselle luvulle teoksessa H. Becker (1982) Art Worlds. Berkeley: University of California Press (1-39).

Benkler, Y. (2006). The Wealth of Networks: How Social Production Transforms Markets and Freedom. New Haven: Yale University Press.

Biörk, H. (2015). Alienation in the White Cube. An Educational Perspective on Curating. Julkaisematon MA-opinnäyte. Helsinki: Aalto-yliopisto.

Bourdieu, P. (1984/2000). Distinction: A social critique of the judgement of taste. Kääntänyt R. Nice. Cambridge, MA: Harvard University Press.

Bourdieu, P. (1993). The Field of Cultural Production. Cambridge: Polity Press.

Bruns, A. (2006). Towards Produsage: Futures for User-Led Content Production. Julkaisussa, F. Sudweeks, H. Hrachovec, \& C. Ess (toim.) Proceedings Cultural Attitudes towards Communication and Technology, Tartto. Haettu osoitteesta http://eprints.qut.edu.au.

Bruns, A. (2008). Blogs, Wikipedia, Second Life and Beyond: From Production to Produsage. Bern: Peter Lang.

Caves, R. (2000). Creative Industries. Contracts Between Art and Commerce. Cambridge, MA and London: Harvard University Press.

Danto, A. (1964). The Artworld. The Journal of Philosophy, 61(19), 571-584.

Dickie, G. (1974). Art and the Aesthetic: An Institutional Analysis. Ithaca: NY: Cornell UP.

Dickie, G. (1984). The Art Circle. New York: Haven.

Dobbs, S.M. \& E.W. Eisner (1987). The Uncertain Profession: Educators in American Art Museums". Journal of Aesthetic Education 21(4), Winter, 77-86.

Haapala, L. (2008). Dokumentaarinen käänne. Neuvotteluja dokumentin ja taideteoksen välillä. Teoksessa P. Rajakari (toim.) Mitä meillä oli ennen Kiasmaa. Kokoelmatoiminnan vaikuttavuus, Helsinki: Valtion taidemuseo.

Hartley, J. (2008). From the Consciousness Industry to Creative Industries: Consumer-created content, social network markets and the growth of knowledge. Teoksessa J. Holt and A. Perren (toim.) Media Industries: History, Theory and Methods. Oxford: Blackwell.

Heinich, N. (2001). La sociologie de l'art. Paris: La Découverte.
Heinich, N. (2014). Le paradigme de l'art contemporain. Paris: Gallimard.

Heinänen, K. (2009). Taiteilija ei näyttelyillä rikastu. Helsingin Sanomat 5.1.2009.

Kaitavuori, K. (2007). Näyttelyprosessi ja Expowiki. Teoksessa P. Kinanen (toim.) Museologia tänäön. Helsinki: Suomen museoliitto (339$341)$.

Howe, J. (2006). The Rise of Crowdsourcing, Wired magazine June.

Kaitavuori, K. (2013). Introduction. Teoksessa K. Kaitavuori, N. Sternfeld \& L. Kokkonen (toim.) It's All Mediating. Outlining and Incorporating the Roles of Curating and Education in the Exhibition Context. Cambridge Scholars Publishing (xiii-xiv).

Kaitavuori, K. (2015). Kuka väittää? Tahiti, taidehistoria tieteenä 03. http://tahiti.fi/032015/tieteelliset-artikkelit/kuka-valittaa/.

Kaitavuori K. \& M. Roine (toim.) (2006). Näyttelyprosessin kuvaus. Museotyöntekijän käsikirjasto 4. Helsinki: Valtion taidemuseo.

Karlsson-Sutisna, S \& H. Kuparinen (2012). Hiljainen hetki Taiteilijan kuolemalle, Helsingin taiteilijaseuran kotisivu http://helsingintaiteilijaseura.fi/hallinta/wp-content/uploads/2012/06/BARRIKADEILLE2.pdf.

Karttunen, S. (2015). Kuinka tutkia kuraattorien esiinnousua ja roolia nykytaiteen tuotannossa? Taustaa taidesosiologiselle tutkimukselle. Tahiti, taidehistoria tieteenä 03. http:// tahiti.fi/03-2015/tieteelliset-artikkelit/kuinka-tutkia-kuraattorien-esiinnousua-ja-roolia-nykytaiteen-tuotannossa-taustaa-taidesosiologiselle-tutkimukselle/.

Kuumola, L. (2013). Mikä meni pieleen? Taiteen eteen tuli kaikenlaista toimintaa, Taide 6, 22-25.

Latour, B. (1999). Pandora's Hope: Essays on the Reality of Science Studies. Cambridge, MA: Harvard University Press.

Latour, B. (2007). Reassembling the Social. An Introduction to Actor-Network-Theory. Oxford: Oxford University Press.

Leadbeater, C. \& P. Miller (2004). The Pro-Am Revolution: How Enthusiasts Are Changing Our Economy and Society. London: Demos.

Levanto, M. (2010). Suomen museoiden yleisöt. Teoksessa S. Pettersson \& P. Kinanen (toim.) Suomen museohistoria. Helsinki: SKS (94109).

Nylén, A. (2015). Jokainen taiteilija on marttyyri ja Kristus. YLE. http://yle.fi/aihe/artikkeli/2015/03/12/antti-nylen-jokainen-taiteilija-marttyyri-ja-kristus (haettu 21.7.2015). 
Palviainen, R. (2010). Museotyön ammatillistuminen. Teoksessa S. Pettersson \& P. Kinanen (toim.) Suomen museohistoria. Helsinki: SKS (315-331).

Pyyhtinen, O. (2012). Kollektiivinen luovuus ja taiteen tuotanto näyttelyinstituutiossa, Tiede \& edistys 37(2), 96-116.

Richter, D. (2012). Artists and Curators as Authors. Competitors, Collaborators or Teamworkers? Teoksessa B. von Bismarck, J. Schafaff \& T. Weski (toim.) Cultures of the curatorial. Berlin: Sternberg Press.

Ryynänen, M (2011). Museopedasta, -taiteesta ja -keskustelusta - Lisäys jo aloitettuun dialogiin, Mustekala http://www.mustekala.info/ node/2176.

Sholette, G. (201 1). Dark Matter: Art and Politics in the Age of Enterprise Culture. London: Pluto Press.

Smith Maguire, J. \& Matthews, J. (toim.) (2014). The Cultural Intermediaries Reader. Los Angeles: Sage.

Smith, T. (2012). Thinking Contemporary Curating, New York: Independent Curators International.

Sorjonen, H. ja O. Sivonen (2015). Taide- ja kulttuurilaitosten yleisötyön muodot, laajuus ja tuloksellisuus. Helsinki: Cupore.

Sternfeld, N. (2010). Unglamorous Tasks: What Can Education Learn from its Political Traditions? e-flux 03 http://www.e-flux.com/journal/view/125.

Tanner, J. (2010). Michael Baxandall and the Sociological Interpretation of Art, Cultural Sociology, 4(2), 231-256.

Toffler, A. (1970). Future Shock. London: Bodley Head.

Venäläinen, A. (2011). Max Ryynänen ja Anni Venäläinen keskustelevat: Mikä museopedagogiikassa mättää? Mustekala http://www. mustekala.info/node/2124.

Wolff, J. (1993 / 1981). The Social Production of Art, 2nd ed. Hampshire \& London: Macmillan Press Ltd.

Woollard, V. (2006). An unsettled profession. Teoksessa C. Lang, J. Reeve \& V. Woollard (toim.). The Responsive Museum: Working with Audiences in the Twenty-first Century. Hampshire: Ashgate.

Ympäristöministeriön tiedote 13.6.2006 http:// www.ymparisto.fi/default.asp? contenti$\mathrm{d}=188260$ \&lan=fi (haettu 15.4.2012).

Zolberg, V. L (2003). Conflicting visions in American art museums. Teoksessa J. Tanner (toim.) The Sociology of Art: A Reader. London: Routledge (194-205). Alun perin julkaisussa Theory and Society 10, (1981), 103-1 25. 


\section{Loppuviitteet}

\section{Suomen osalta ks. myös Palviainen 2010.}

2. For a symphony orchestra to give a concert, for instance, instruments must have been invented, manufactured and maintained, a notation must have been devised and music composed using that notation, people must have learned to play the notated notes on the instruments, times and places for rehearsal must have been provided, ads for the concert must have been placed, publicity arranged and tickets sold, and an audience capable of listening to and in some way understanding and responding to the performance must have been recruited.

\section{Taidemaailma-käsite on alun alkaen Danton lanseeraama.}

4. Dickie julkaisi aiemman version teoriasta jo vuonna 1971. Vuonna 1984 taiteen ja taidemaailman määritelmä oli hioutunut näin: 1 . An artist is a person who participates with understanding in the making of a work of art. 2. A work of art is an artifact of a kind created to be presented to an artworld public. 3. A public is a set of persons the members of which are prepared in some degree to understand an object which is presented to them. 4. The artworld is the totality of all artworld systems. 5. An artworld is a framework for the presentation of a work of art by an artist to an artworld public. (Dickie 1984.)

5. Victoria Alexanderin kulttuuritimantti on esimerkki lähestymistavasta, jossa molemmat erottelut ovat voimassa: timantin kärjet ovat vertikaalisti yhteiskunta ja taide ja horisontaalisti taiteilijat (tekijät) ja vastaanottajat (kuluttajat). Kuvion keskelle Alexander sijoittaa välittäjät (Alexander 2003).

6. Painotukset vaihtelevat, mutta esim. Tanner kuvaa miten 'production of culture'-suuntauksen edustajat pitävät sosiologisesti painottunutta taidehistoriaa liian taideteoskeskeisenä ja puutteellisena, koska se ei keskity 'sosiaaliseen kontekstiin' (Tanner 2010, s. 238).

7. Suomessa Ateneumin historia tuntee useita yleisöä opastaneita amanuensseja ja intendenttejä, joista suosituin oli varmasti Aune Lindström (Levanto 2010).

8. Elliot Eisnerin mukaan pedagogi on "the advocate of the viewer" ja kuraattori on "the advocate of the work of art" (Dobbs \& Eisner 1987).
Nykyaikaan päivitettynä saman toteaa Terry Smith (2012, s. 45).

9. Ks. tarkemmin Kaitavuori 2015. Yleisöön suuntautuvan toiminnan toimintafilosofian muutoksia heijastavat $\mathrm{mm}$. sen muuttuvat nimitykset valistuksesta pedagogiikkaan ja edelleen yleisötyöksi.

10. Sari Karttunen valottaa Cuporessa tekeillä olevan tutkimuksensa lähtökohtia artikkelissa Karttunen 2015. Yleisötyön rahoituksen vaikuttavuudesta ks. Sorjonen \& Sivonen 2015. Aalto-yliopiston Curating, Managing and Mediating Art (CuMMA)-ohjelma on alkanut tuottaa maisteritasoisia opinnäytteitä kuraattorien ja museopedagogien/yleisötyöläisten toiminnasta ja näiden välisestä työnjaosta; myös saman oppilaitoksen kuvataidekasvattajat ovat viimeaikoina tehneet gradujaan samoista aihepiiristä. Samoin Kuvataideakatemiassa kuraattoreja kouluttavasta Praxis-maisteriohjelmasta on alkanut tulla opinnäytteitä alalta.

11. Projektin kuvaus perustuu Leevi Haapalan artikkeliin (Haapala 2008) sekä kirjeenvaihtoon ja keskusteluihin kuraattorien ja teknisen henkilökunnan kanssa sekä yhden osallistujan kanssa.

12. Cultural intermediary -käsite on alun perin Bourdieulta (Bourdieu 1984).

13. Heinichin muotoilee asian niin, että nykytaide ikään kuin imee itseensä sekä sosiaalisen että taiteellisen kontekstin: ne eivät ole jossain taustalla vaan teoksen rakenteellisia osia (Heinich 2014, s. 114-117).

14. Norjalainen taiteilija Matias Faldbakken ilmaisi selkeästi Institution2-konferenssissa, että hän tekee taiteensa "primaariyleisölle", joka koostuu lähipiirin taiteilijoista ja muista ammattilaisista. Näiden mielipide on tärkein. Jossain sen ulkopuolella on "sekundaarinen yleisö", joka ei kiinnosta häntä lainkaan ja jonka kanssa hänellä ei sanojensa mukaan ole mitään tekemistä. Saksalainen instituutionjohtaja puolestaan sanoi puheenvuoronsa aluksi, ettei oikeastaan tiennyt, miksi oli tässä paneelissa, koska häntä ja hänen instituutiotaan ei museopedagogia ja yleisötyö mitenkään kiinnosta eikä heillä ole siihen ketään työntekijää saati pedagogista ohjelmaa. Lopuksi yleisössä istuva taiteilija esitti, että kaikki muu kuin suoraan taiteilijoille koh- 
dennettu raha on "waste of money". Muistiinpanot Notions on the audience, interaction and educational programs -paneelista, Institution2 - Art Institutions: The Ethics and Aesthetics of Working with Contemporary Art, International Conference 3.-4.12.2003 Kiasma.

15. Esimerkkejä kriittisistä ja vihamielisistä kommenteista lähimenneisyydessä on $\mathrm{mm}$. Mustekala-verkkojulkaisun debatti (Venäläinen 2011, Ryynänen 2011) sekä Leena Kuumolan närkästyminen Kiasman lapsille suunnatusta toiminnasta näyttelysaleissa (Kuumola 2013).

16. Max Ryynänen esimerkiksi kauhistelee sitä, että museoiden toimintaa viritetään "kadunmiehen ymmärryksen tasolle" ja sitä ohjaa "Matti ja Mervi Meikäläisen ymmärryksen rajat". Tästä asiaintilasta on vastuussa "pedafasismi" ja "museopedastalinismi" (Ryynänen 2011, Venäläinen 2011). Värikkäästä kielenkäytöstä huolimatta pedagogisesta totalitarismista tai rahvaan ymmärryksestä ei esitetä yhtään konkreettista esimerkkiä.

17. Tähtikuraattorien historiasta ja kuraattorien taiteilijuudesta ks. esim. Richter 2012; ja vastapainoksi pedagogeista Sternfeld 2010.

18. Ks. taideteoksen verkostokuvauksesta myös Pyyhtinen 2012.

19. Nykytaiteessa kyseessä onkin Heinichin mukaan kokonaan uusi paradigma (Heinich 2014). 